\title{
Effects of Recirculating Aquaculture System Wastewater on Anammox Performance and Community Structure
}

\author{
Jonathan A. C. Roques ${ }^{1,2,+} \mathbb{D}$, Federico Micolucci ${ }^{1,2,+} \mathbb{D}^{\text {, }}$, Suguru Hosokawa ${ }^{3}$, Kristina Sundell ${ }^{1,2}$ \\ and Tomonori Kindaichi ${ }^{3, *}$ (D) \\ 1 Department of Biological and Environmental Sciences, University of Gothenburg, \\ P.O. Box 463, SE-405 30 Gothenburg, Sweden; jonathan.roques@bioenv.gu.se (J.A.C.R.); \\ federico.micolucci@bioenv.gu.se (F.M.); kristina.sundell@bioenv.gu.se (K.S.) \\ 2 Swedish Mariculture Research Center (SWEMARC), University of Gothenburg, \\ P.O. Box 463, SE-405 30 Gothenburg, Sweden \\ 3 Department of Civil and Environmental Engineering, Graduate School of Advanced Science and Engineering, \\ Hiroshima University, 1-4-1 Kagamiyama, Higashihiroshima 739-8527, Japan; sgr.27032@gmail.com \\ * Correspondence: tomokin@hiroshima-u.ac.jp; Tel.: +81-82-424-5718 \\ + Contributed equally to the study.
}

check for updates

Citation: Roques, J.A.C.; Micolucci, F.; Hosokawa, S.; Sundell, K.;

Kindaichi, T. Effects of Recirculating

Aquaculture System Wastewater on Anammox Performance and Community Structure. Processes 2021, 9, 1183. https://doi.org/10.3390/ pr9071183

Academic Editors: Albert Magrí and Tommaso Lotti

Received: 14 June 2021

Accepted: 3 July 2021

Published: 7 July 2021

Publisher's Note: MDPI stays neutral with regard to jurisdictional claims in published maps and institutional affiliations.

Copyright: (c) 2021 by the authors. Licensee MDPI, Basel, Switzerland. This article is an open access article distributed under the terms and conditions of the Creative Commons Attribution (CC BY) license (https:/ / creativecommons.org/licenses/by/ $4.0 /)$.

\begin{abstract}
Recirculating aquaculture systems (RAS) are good candidates for the sustainable development of the aquaculture sector. A current limitation of RAS is the production and accumulation of nitrogenous waste, which could affect fish health. We investigated the potential of the anaerobic ammonia oxidation (anammox) process to treat marine wastewater from a cold-water RAS. We show that the marine anammox bacteria Candidatus Scalindua is a promising candidate. However, its activity was affected by unknown compounds in the RAS wastewater and/or the sub-optimum content of essential trace elements (TEs). Anammox activity dropped to $2 \%$ and $13 \%$ in $\mathrm{NH}_{4}{ }^{+}$and $\mathrm{NO}_{2}{ }^{-}$removal, respectively, when $\mathrm{NO}_{3}$-rich RAS wastewater was used as a medium in the absence of TE supplementation. A TE supplementation was added to the RAS wastewater in a subsequent phase, and a recovery in anammox activity was shown (25\% and $24 \%$ in $\mathrm{NH}_{4}{ }^{+}$and $\mathrm{NO}_{2}{ }^{-}$removal, respectively). Future studies need to identify the unknown factor and determine the specific needs regarding TE for optimal RAS wastewater treatment by Candidatus Scalindua.
\end{abstract}

Keywords: Candidatus Scalindua; anaerobic ammonium oxidation (anammox); recirculating aquaculture system (RAS)

\section{Introduction}

The world population is expected to reach 9.7 billion by 2050 [1]. Therefore, there is an urgent need to increase nutritious and sustainable food production [2]. There is a global consensus about the increasing importance of aquaculture as an essential source of food. Indeed, the aquaculture sector currently accounts for almost 50\% of the global fish production for human consumption and is steadily growing [3]. However, the production methods' intensification has led to environmental concerns regarding, e.g., eutrophication, caused by the leakage of nutrients to the environment, especially in open-water systems [4]. Closed containment systems such as recirculating aquaculture systems (RAS) allow for a high degree of water reuse as well as ensuring better control of the farming environment, resulting in reduced ecological impact [5-7]. RAS are therefore of interest to the development of sustainable aquaculture. In RAS, ammonium $\left(\mathrm{NH}_{4}{ }^{+}\right)$is oxidized into nitrate $\left(\mathrm{NO}_{3}{ }^{-}\right)$via nitrite $\left(\mathrm{NO}_{2}{ }^{-}\right)$by nitrifying bacteria in aerobic biofilm reactors [8]. $\mathrm{NO}_{3}{ }^{-}$can accumulate over time in an RAS and can reach concentrations of up to 100-1000 $\mathrm{mg} \mathrm{L}^{-1}$ depending on the RAS design and management $[9,10]$. Over time, such levels may negatively affect fish health and welfare if not appropriately managed through denitrification or regular water exchanges [11,12]. Ambient levels below $10 \mathrm{mg} \mathrm{NO}_{3}{ }^{-}-\mathrm{N} \mathrm{L}^{-1}$ (freshwater) and $20 \mathrm{mg}$ 
$\mathrm{NO}_{3}{ }^{-}-\mathrm{N} \mathrm{L}^{-1}$ (seawater) are recommended to avoid adverse effects in fish [11]. Specific denitrification compartments, where the biological conversion of $\mathrm{NO}_{3}{ }^{-}$to nitrogen gas $\left(\mathrm{N}_{2}\right)$ occurs, are not always present in RAS, as denitrification is an inherently unstable process that can lead to the creation and accumulation of intermediate substances (e.g., $\mathrm{NO}_{2}{ }^{-}, \mathrm{NO}$ and $\mathrm{N}_{2} \mathrm{O}$ ) that can be toxic to fish and harmful to the environment $[13,14]$. Consequently, most of the current RAS are partial RAS, only using nitrification steps and requiring $>10 \%$ water exchange per day in order to avoid the accumulation of $\mathrm{NO}_{3}{ }^{-}$. This results in a relatively high use of water and the production of nitrate-rich wastewater. New water treatment solutions for increased re-circulation of the culture water will aid in developing RAS that are more sustainable and productive.

Anaerobic ammonia oxidation (anammox) is a microbial process that converts $\mathrm{NH}_{4}{ }^{+}$and $\mathrm{NO}_{2}{ }^{-}$directly into $\mathrm{N}_{2}$ gas [15]. This process recently attracted attention as an energy-saving and highly efficient nitrogen removal technology in wastewater treatment plants [16,17] and is, thus, a promising candidate for the nitrogen removal process in RAS [18]. The presence of anammox bacteria has been detected in many freshwater and marine environments with limited oxygen availability [19]. The presence and subsequent activity of anammox bacteria have been detected in microbial biofilm from the denitrifying compartment in both freshwater and marine RAS [20-23]. In 2009, Tal and colleagues used anammox coupled with denitrification for the first time in a pilot warm-water RAS, achieving both a recirculation rate and animal survival of $99 \%$ [24].

A marine anammox bacterium named Candidatus Scalindua sp. (hereafter Ca. Scalindua) was successfully enriched from coastal surface sediment collected from Hiroshima Bay (Japan) $[25,26]$. Ca. Scalindua is a promising microbial component to mitigate environmental problems of aquaculture due to its high anammox activity under high salinity and low temperature conditions $[27,28]$. In addition, the anammox process avoids the microbial pathways through which toxic substances (e.g., $\mathrm{N}_{2} \mathrm{O}$ ) are formed in aquaculture systems.

In the present study, we investigated the behavior of $C a$. Scalindua in wastewater from a commercial, cold-water marine RAS (Table 1). A newly started $C a$. Scalindua reactor was exposed to artificial seawater enriched with $\mathrm{NH}_{4}{ }^{+}, \mathrm{NO}_{2}{ }^{-}$and essential trace elements (TEs, including $\mathrm{B}, \mathrm{Co}, \mathrm{Cu}, \mathrm{Fe}, \mathrm{Mn}, \mathrm{Mo}, \mathrm{Ni}$, Se and $\mathrm{Zn}$ ) (control) and RAS wastewater in the absence and presence of TEs. The anammox performance (nitrogen loading and removal rates, $\mathrm{NH}_{4}{ }^{+}$and $\mathrm{NO}_{2}{ }^{-}$removal efficiencies) was evaluated alongside changes in the microbial community composition under the different conditions. The aim of this first pilot experiment was to show the anammox bacteria response to RAS wastewater under controlled conditions (optimal $\mathrm{pH}$, salinity, temperature, $\mathrm{NH}_{4}{ }^{+}$and $\mathrm{NO}_{2}{ }^{-}$concentrations).

Table 1. Physicochemical characteristics of the RAS wastewater.

\begin{tabular}{|c|c|c|c|c|c|c|c|}
\hline Parameter & $\begin{array}{l}\text { Salinity } \\
(\% \text { ) }\end{array}$ & $\begin{array}{c}\mathrm{NH}_{4}^{+} \\
\left(\mathrm{mg}-\mathrm{N} \mathrm{L}^{-1}\right)\end{array}$ & $\begin{array}{c}\mathrm{NO}_{2}^{-} \\
\left(\mathrm{mg}-\mathrm{N} \mathrm{L}^{-1}\right)\end{array}$ & $\begin{array}{c}\mathrm{NO}_{3}^{-} \\
\left(\mathrm{mg}-\mathrm{N} \mathrm{L}^{-1}\right)\end{array}$ & $\mathrm{pH}$ & $\begin{array}{c}\text { TSS } \\
\left(\mathrm{mg} \mathrm{L}^{-1}\right)\end{array}$ & $\begin{array}{c}\text { TOC } \\
\left(\mathrm{mg}-\mathrm{C} \mathrm{L}^{-1}\right)\end{array}$ \\
\hline Value & 14.5 & 0.25 & 0.017 & 29.22 & 7.5 & 70.5 & 6.8 \\
\hline
\end{tabular}

\section{Materials and Methods}

\subsection{RAS Wastewater Collection and Characteristics}

RAS wastewater (20 L, Table 1) was collected from Smögenlax Aquaculture AB, Kungshamn, Sweden, a pilot-scale research and development facility for the development of land-based seawater RAS at low temperatures, in June 2019 [29]. The water samples were stored in two 5-L and ten 10-L plastic containers, immediately frozen $\left(-80^{\circ} \mathrm{C}\right)$ and subsequently shipped to the Department of Civil and Environmental Engineering at Hiroshima University (Japan) and kept frozen until further use. The fish species in the RAS were rainbow trout, Oncorhynchus mykiss, with an average weight of $1.3 \pm 0.3 \mathrm{~kg}$ and were kept at a density of $40 \mathrm{~kg} \mathrm{~m}^{-3}$ ([29] and Bengt Gunnarsson, personal communication). 


\subsection{Reactor Operation}

$\mathrm{Ca}$. Scalindua granules were harvested from an up-flow column anammox stock culture that has been operating with a continuous supply of inorganic nutrient media containing $\mathrm{NH}_{4}{ }^{+}\left(28 \mathrm{mg}-\mathrm{N} \mathrm{L}^{-1}\right)$ and $\mathrm{NO}_{2}{ }^{-}\left(34 \mathrm{mg}-\mathrm{N} \mathrm{L}^{-1}\right)$ [30] for more than 10 years [26,31,32]. Biomass of $1 \mathrm{~g}$ (wet weight) was used as inoculum in a glass column reactor $(\varnothing 30 \mathrm{~mm}$; volume, $76 \mathrm{~cm}^{3}$; KF-30, AS ONE, Tokyo, Japan) with a nonwoven fabric sheet (Japan Vilene, Tokyo, Japan) as the biofilm carrier material (Figure 1).

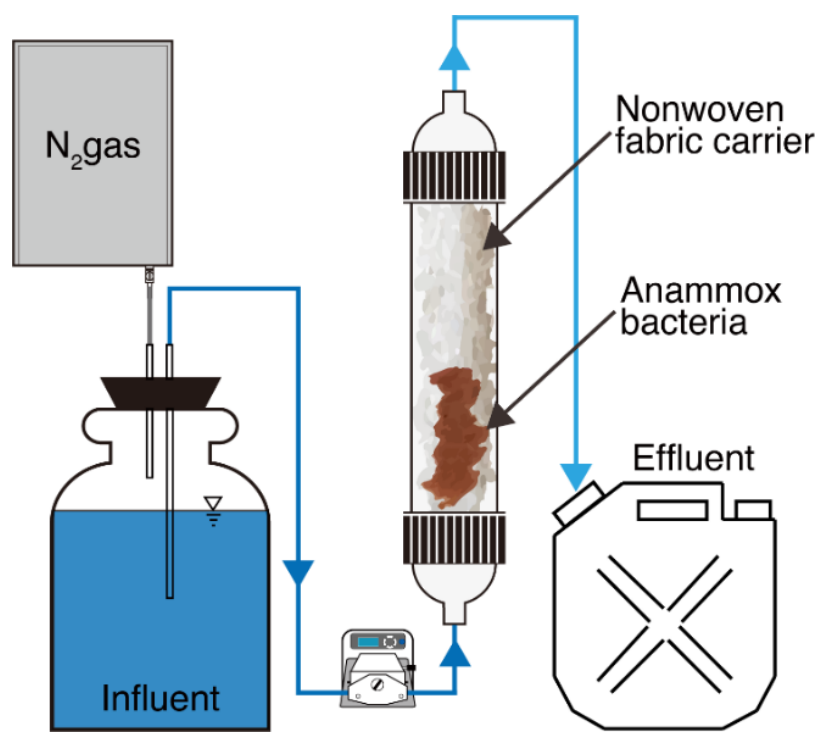

Figure 1. Schematic drawing of the up-flow column reactor.

The reactor was operated for 150 days in 5 different phases (Table 2). During Phase 1 (days 0-65) and Phase 5 (days 104-150), the reactor was fed with synthetic marine wastewater (SEALIFE, Marinetech, Tokyo, Japan) supplemented with nitrogen $\left(\mathrm{NH}_{4}{ }^{+}\right.$and $\mathrm{NO}_{2}{ }^{-}$) and nine TEs $(\mathrm{B}, \mathrm{Co}, \mathrm{Cu}, \mathrm{Fe}, \mathrm{Mn}, \mathrm{Mo}, \mathrm{Ni}$, Se and $\mathrm{Zn})$, as described by van de Graaf and colleagues (see Supplementary Material, Table S1 and [30]). During Phases 2-4 (days 65-104), the reactor was exposed to the RAS wastewater. The RAS wastewater characteristics were adjusted to match the standard medium for the optimal functioning and growth of $\mathrm{Ca}$. Scalindua in laboratory conditions in terms of temperature $\left(20^{\circ} \mathrm{C}\right)$, salinity $(26.2 \%), \mathrm{NH}_{4}{ }^{+}\left(28 \mathrm{mg}-\mathrm{N} \mathrm{L}^{-1}\right), \mathrm{NO}_{2}{ }^{-}\left(34 \mathrm{mg}-\mathrm{N} \mathrm{L}^{-1}\right)$ and inorganic carbon $\left(\mathrm{KHCO}_{3}\right.$, $\left.1000 \mathrm{mg} \mathrm{L}^{-1}\right)[25,26,31]$. Those parameters were maintained constantly throughout the different experimental phases. The initial hydraulic retention time (HRT) was $2.3 \mathrm{~h}$. During Phases 1,3 and 5, the wastewater was supplemented with a mix of TEs in order to determine the activity of $C a$. Scalindua in the presence (Phases 1, 3 and 5) or absence (Phases 2 and 4) of TEs. This TE mix was developed when the first freshwater anammox species was enriched and is currently used as a standard in anammox cultures worldwide [30]. Each time, the influent was flushed with $\mathrm{N}_{2}$ gas for at least $30 \mathrm{~min}$ before adding the components to achieve a concentration of dissolved oxygen below $0.1 \mathrm{mg} \mathrm{L}^{-1}$. The influents were continuously introduced into the reactor using a peristaltic pump (Masterflex L/S Economy Drive, Cole-Parmer Instruments, Vernon Hills, IL, USA).

\subsection{Analytical Methods}

The total nitrogen (TN) loading and removal rates were calculated based on the concentrations of $\mathrm{NH}_{4}{ }^{+}, \mathrm{NO}_{2}{ }^{-}$and $\mathrm{NO}_{3}{ }^{-}$as well as the HRT. Salinity was determined using a conductivity meter (LAQUAact ES-71, Horiba, Kyoto, Japan). Analyses of total suspended solids (TSS) were carried out in accordance with the Standard Methods [33]. The $\mathrm{pH}$ was measured using a $\mathrm{pH}$ meter (F-52, HORIBA, Kyoto, Japan). Total organic carbon (TOC) was measured using a TOC analyzer (Shimadzu TOC-VCSH, Kyoto, Japan, with a detection limit of $50 \mu \mathrm{g} \mathrm{L}^{-1}$ ) as described previously [34]. 
Table 2. Operational conditions of the column reactor.

\begin{tabular}{|c|c|c|c|c|c|c|c|c|c|}
\hline \multirow{2}{*}{ Phase } & \multirow{2}{*}{$\begin{array}{l}\text { Period } \\
\text { (d) }\end{array}$} & \multirow{2}{*}{ AS/RAS ${ }^{1}$} & \multirow{2}{*}{ TEs $^{2}$} & \multirow{2}{*}{$\begin{array}{l}\text { HRT } \\
\text { (h) }{ }^{3, *}\end{array}$} & \multirow{2}{*}{$\begin{array}{c}\text { NLR } \\
(\text { g-TN L } \\
\left.-1 \text { day }^{-1}\right)^{4, *}\end{array}$} & \multicolumn{2}{|c|}{$\mathrm{pH}^{*}$} & \multicolumn{2}{|c|}{ Salinity $(\%) *$} \\
\hline & & & & & & Influent & Effluent & Influent & Effluent \\
\hline 1 & $0-65$ & AS & + & 2.3 & $0.72 \pm 0.03$ & $7.62 \pm 0.16$ & $7.82 \pm 0.14$ & $25.5 \pm 2.9$ & $25.6 \pm 3.1$ \\
\hline 2 & $65-77$ & RAS & - & 2.4 & $1.02 \pm 0.06$ & $7.80 \pm 0.24$ & $7.95 \pm 0.20$ & $26.6 \pm 0.1$ & $26.2 \pm 1.0$ \\
\hline 3 & $77-96$ & RAS & + & 4.8 & $0.48 \pm 0.03$ & $7.57 \pm 0.16$ & $7.78 \pm 0.09$ & $26.1 \pm 0.6$ & $26.2 \pm 0.8$ \\
\hline 4 & 96-104 & RAS & - & 5.1 & $0.45 \pm 0.01$ & $7.47 \pm 0.06$ & $7.67 \pm 0.15$ & $26.2 \pm 0.7$ & $26.3 \pm 0.4$ \\
\hline 5 & $104-150$ & AS & + & 5.1 & $0.33 \pm 0.02$ & $7.66 \pm 0.19$ & $7.91 \pm 0.12$ & $27.2 \pm 0.6$ & $27.2 \pm 0.8$ \\
\hline
\end{tabular}

${ }^{1}$ AS, Artificial seawater; RAS, Recirculating aquaculture system wastewater. ${ }^{2}$ TEs, Trace element mix, reported by van de Graaf and colleagues [30]; see also Supplementary Material, Table S1. ${ }^{3}$ HRT, Hydraulic retention time. ${ }^{4}$ NLR, Nitrogen loading rate. ${ }^{*}$ Values show the average and standard deviation during the different phases, measured 2-4 times per week (Phases 1 and 5 ) and 3-5 times per week (Phases 2-4).

The $\mathrm{NH}_{4}{ }^{+}$concentration was determined using Nessler's method with a UV-visible spectrophotometer (DR-2800, Hach-Lange, Loveland, CO, USA) according to the manufacturer's recommendations (Hach-Lange, Loveland, USA, Method 8038, with a detection limit of $0.02 \mathrm{mg}-\mathrm{N} \mathrm{L}^{-1}$ ). The concentrations of $\mathrm{NO}_{2}{ }^{-}$and $\mathrm{NO}_{3}{ }^{-}$were determined using ion-exchange chromatography (HPLC 20A; Shimadzu, Kyoto, Japan) with a Shodex Asahipak NH2P-50 4D anion column (Showa Denko, Tokyo, Japan) and a UV-VIS detector (SPD-20AV, Shimadzu) after filtration of samples through 0.2-micrometer pore-size PTFE membranes (Advantec, Tokyo, Japan) [17]. The detection limit for both $\mathrm{NO}_{2}{ }^{-}$and $\mathrm{NO}_{3}{ }^{-}$ was $0.5 \mathrm{mg}-\mathrm{N} \mathrm{L}^{-1}$.

\subsection{Microbial Community Analysis}

In order to determine the potential changes in the microbial community composition during the different phases, biomass samples for amplicon sequencing were collected from the reactor at days 0, 78 and 104. DNA was extracted using a FastDNA SPIN kit for soil (MP Biomedicals, Santa Ana, USA). PCR amplification of the bacterial 16S rRNA gene was performed with a primer set for amplification of the V3-V4 region as follows: 341F (5'-CCTACGGGNGGCWGCAG-3') and 805R (5'-GGACTACHVGGGTATCTAATCC$\left.3^{\prime}\right)$. The details of the PCR amplification were described previously [34]. PCR products were purified using the Agencourt AMPure XP system (Beckman Coulter, Brea, CA, USA) according to the manufacturer's instructions. Purified DNA was sequenced using a MiSeq platform with a MiSeq reagent kit (v.3; Illumina, San Diego, CA, USA).

Obtained sequences were trimmed and assembled as described previously [35]. Sequence data were analyzed using QIIME 2 Core 2020.2 distribution [36]. Operational taxonomic units (OTUs) were assigned with the SILVA 132 database [37]. OTUs that accounted for more than $0.5 \%$ of the total reads were used for bar plots. The sequence data in the present study were deposited in the DNA Data Bank of Japan (DDBJ) database under the DDBJ/EMBL/GenBank accession number DRA010899.

\subsection{Fluorescence In Situ Hybridization (FISH)}

Biomass samples were collected from the up-flow column reactor at days 0,78 and 104. Sample fixation and the FISH procedure were described previously [25]. The probes used in this study were as follows: a mixture of EUB338, II, III and IV probes labeled with Alexa Fluor 488 specific for all bacteria $[38,39]$ and BS820 probes labeled with Alexa Fluor 555 specific for $\mathrm{Ca}$. Scalindua [39]. Hybridized samples were observed with an Axiomager M1 epifluorescence microscope with a 100-watt HBO lamp. Images were obtained using an AxioCam MRm version 3 FireWiremonocrome camera and AxioVision software, version 4.5 (Carl Zeiss, Oberkochen, Germany).

\section{Results}

\subsection{Reactor Performance}

During Phase 1 (synthetic wastewater and TEs), the TN removal rate gradually increased while maintaining a constant TN loading rate (Figure 2). Once the reactor reached a stable state (days 45-60), the average TN loading and removal rate were $0.72 \pm 0.03$ 
and $0.61 \pm 0.03 \mathrm{~g}-\mathrm{TN} \mathrm{L}^{-1}$ day $^{-1}$, respectively (HRT $2.3 \mathrm{~h}$ ). At the end of Phase 1 , the removal efficiency had reached $93 \%$ for $\mathrm{NH}_{4}{ }^{+}$and $100 \%$ for $\mathrm{NO}_{2}{ }^{-}$. The stoichiometry ratio of $\mathrm{NO}_{2}{ }^{-} / \mathrm{NH}_{4}{ }^{+}$and $\mathrm{NO}_{3}{ }^{-} / \mathrm{NH}_{4}{ }^{+}$was 1.56 and -0.16 , respectively. All these parameters suggested a successful establishment of the anammox process in the reactor [31,40-42].
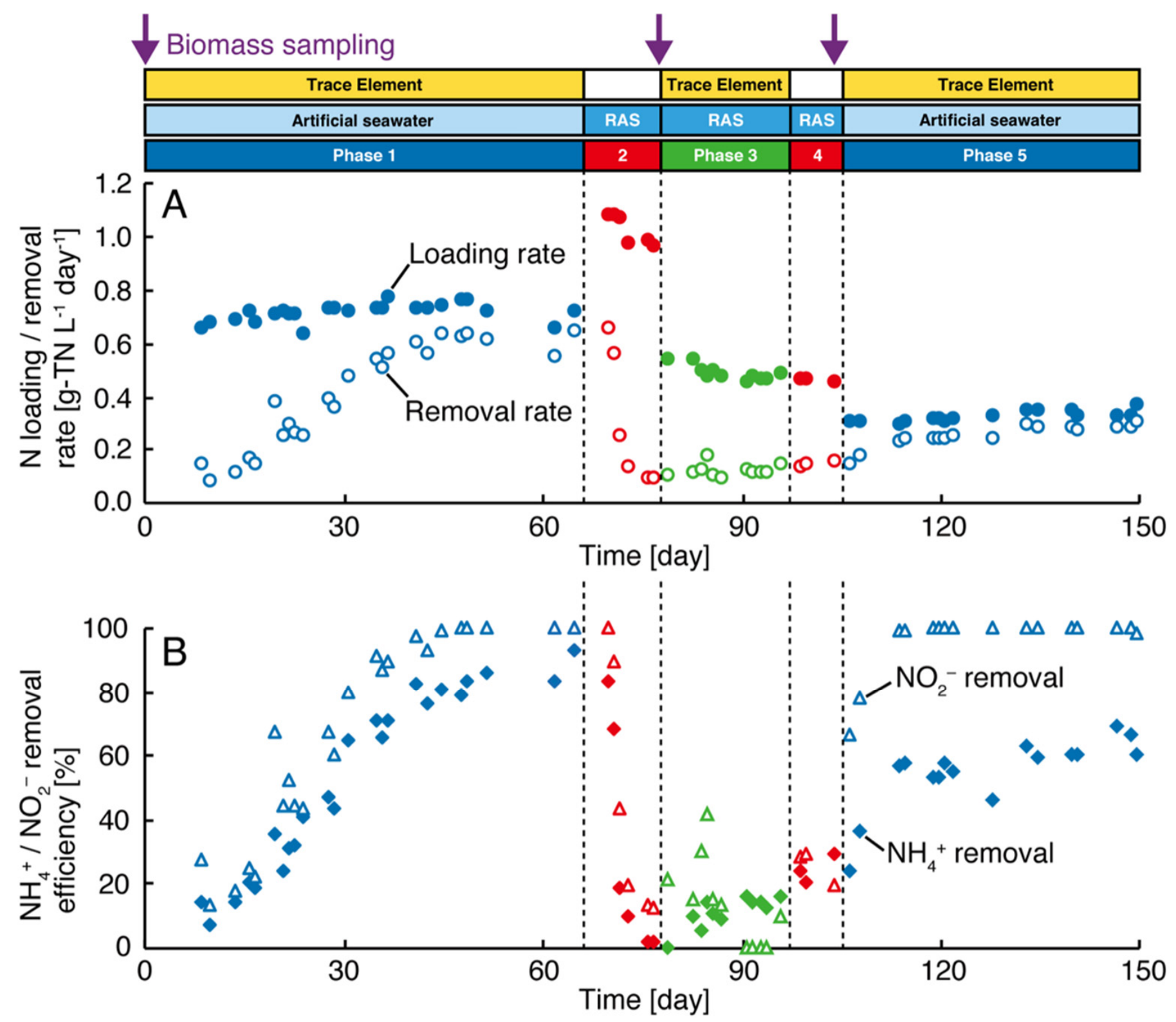

Figure 2. Anammox performance in the reactor. (A) Nitrogen loading and removal rates (filled and open circles). (B) $\mathrm{NH}_{4}{ }^{+}$ and $\mathrm{NO}_{2}{ }^{-}$removal efficiencies (filled diamonds and open triangles). Dotted lines indicate changes in the operational phase (artificial seawater or RAS wastewater, the presence of TEs). Purple arrows indicate biomass sampling on days 0, 78 and 104. RAS, recirculating aquaculture system wastewater. 
During Phase 2, the use of RAS wastewater instead of artificial seawater without TEs resulted in a drastic decrease in the TN removal rate. The average TN loading rate during this phase was higher than that in Phase $1\left(1.02 \pm 0.06 \mathrm{~g}^{-\mathrm{TN} \mathrm{L}^{-1}} \mathrm{day}^{-1}\right)$ due to the presence of higher $\mathrm{NO}_{3}-$ in RAS wastewater (Table 1). At the end of Phase 2, the removal efficiencies of $\mathrm{NH}_{4}{ }^{+}$and $\mathrm{NO}_{2}{ }^{-}$were only $2 \%$ and $13 \%$, respectively (HRT $2.4 \mathrm{~h}$ ), and the TN removal rate was $0.09 \mathrm{~g}^{-\mathrm{TN} \mathrm{L}}{ }^{-1} \mathrm{day}^{-1}$. These results clearly indicate that there was a negative effect of the RAS wastewater and/or the absence of TEs on the activity of anammox bacteria.

During Phase 3, RAS wastewater was used in combination with TEs, and the HRT was increased to $4.8 \mathrm{~h}$ (i.e., decrease in TN loading rate). The $\mathrm{NH}_{4}{ }^{+}$and $\mathrm{NO}_{2}{ }^{-}$removal efficiencies slightly recovered during this phase, suggesting that the RAS wastewater was lacking some key TEs and/or the TN loading rate was too high for maintaining the anammox activity from Phase 2. On days 91-94, the removal efficiency of $\mathrm{NO}_{2}{ }^{-}$fell to almost zero due to accidental temporary oxygen contamination, which was fixed on day 94, prior to the start of the next phase. In order to investigate which factor(s) (TEs/TN loading rate) negatively affected the anammox activity during Phase 2, the TEs in the RAS wastewater were removed during Phase 4 while keeping the same TN loading rate as in Phase 3 to investigate the effect of TEs. The $\mathrm{NH}_{4}{ }^{+}$and $\mathrm{NO}_{2}{ }^{-}$removal efficiencies were slightly improved during this phase $(25.5 \pm 5.4 \%$ and $24.6 \pm 4.5 \%$ on average, respectively), suggesting that TE supplementation was not necessary for a short period under the Phase 4 condition. However, as TEs are strongly related to the cell biosynthesis and cell division in anammox bacteria, the impact of TE depletion and the specific TE requirements of $C a$. Scalindua culture need to be investigated for at least two weeks, which is the generation time of $\mathrm{Ca}$. Scalindua [25]. On the other hand, the increase in TN loading rate was due to the high $\mathrm{NO}_{3}{ }^{-}$concentration contained in the RAS wastewater. Since the tolerance to $\mathrm{NO}_{3}{ }^{-}$of $\mathrm{Ca}$. Scalindua is unclear, it also needs to be investigated in the future.

During Phase 5, artificial seawater was used with TEs and $5.1 \mathrm{~h}$ of HRT. The decrease in $\mathrm{TN}$ loading rate was due to the lower $\mathrm{NO}_{3}{ }^{-}$concentration in the artificial seawater (0.8 mg-N L ${ }^{-1}$ ) compared to the RAS wastewater; the $\mathrm{NO}_{3}{ }^{-}$concentration in the RAS wastewater was higher (29.22 $\mathrm{mg}^{-\mathrm{N} \mathrm{L}^{-1}}$, Table 1) due to the absence of a denitrification compartment in the Swedish farm. The $\mathrm{NH}_{4}{ }^{+}$and $\mathrm{NO}_{2}{ }^{-}$removal efficiencies in Phase 5 were at similar levels as in Phase 1 within 8 days of operation. All these observations during the different phases of operation suggest that the normal anammox activity was probably affected by the presence of unknown compounds (e.g., presence of other organic and inorganic residues from feces and uneaten feed) in the RAS wastewater.

\subsection{Microbial Community Analysis and FISH}

A total of 27,115,21,327 and 39,312 non-chimeric reads and 95, 131 and 138 operational taxonomic units (OTUs) were obtained on days 0,78 and 104, respectively. In this study, OTUs that accounted for more than $0.5 \%$ of the total reads were used for the analysis, and OTUs accounting for less than $0.5 \%$ of the total reads were grouped as "Others" (Figure 3). $\mathrm{Ca}$. Scalindua was identified as the most abundant species in the reactor. Interestingly, the relative abundances of $\mathrm{Ca}$. Scalindua did not change over time $(29.6 \%$ in the inoculum to $27.9 \%$ on day 104), even during the phase with RAS wastewater.

This stable population of $\mathrm{Ca}$. Scalindua during the experiment was also supported by FISH observations (Figure 4). Therefore, the decrease in the TN removal rate was probably not caused by a decrease in anammox bacterial population abundance but rather by a decrease in the anammox activity of the Ca. Scalindua present. 


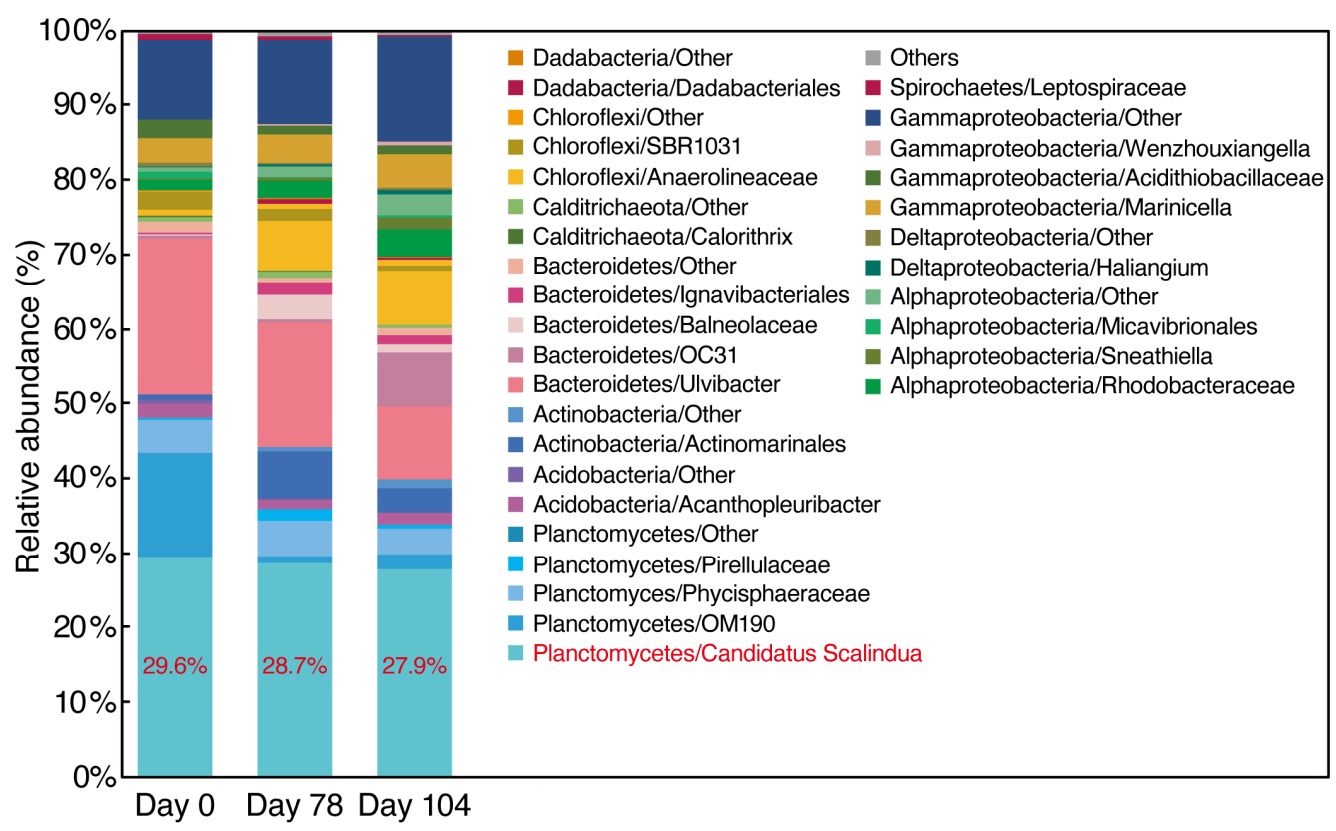

Figure 3. Microbial community composition after 0, 78 and 104 days of operation, based on 16S rRNA gene amplicon sequencing. Red percentages correspond to the relative abundance of marine anammox bacteria.
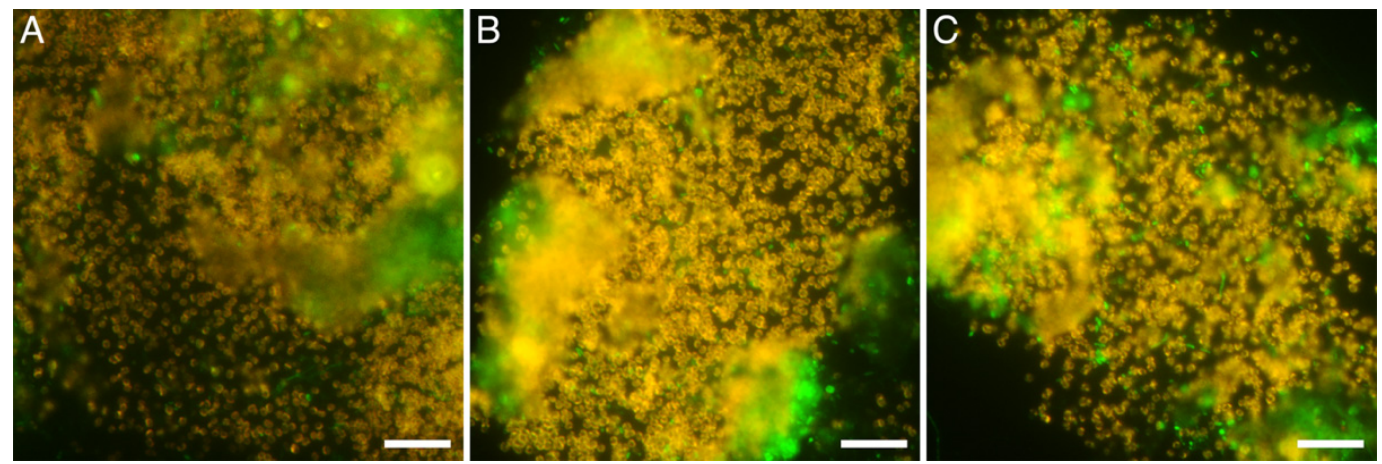

Figure 4. FISH micrographs of biomass collected from the column reactor at days 0 (A), 78 (B) and 104 (C). FISH was performed with Alexa-Fluor-488-labeled EUB338mix probes (green) for all bacteria and Alexa-Fluor-555-labeled BS820 probes (red) for $\mathrm{Ca}$. Scalindua. Ca. Scalindua appears yellow and other bacteria appear green. Scale bars represent $10 \mu \mathrm{m}$.

\section{Discussion}

\subsection{Reactor Performance}

The observed decrease in anammox activity (Figure 2) could be due to unknown compounds present in the RAS wastewater or the imbalance of certain TEs in the wastewater. Previous and current anammox bacteria cultivations worldwide, including marine species, have been and are being performed using a synthetic feed containing nine different TEs. This cultivation protocol was developed over 25 years ago when the first freshwater anammox species was enriched [30]. Different species of anammox bacteria may have different TE requirements; in particular, marine anammox bacteria such as $\mathrm{Ca}$. Scalindua may have different requirements than freshwater anammox species do [43,44]. Unfortunately, we were not able to measure TEs in the pure RAS wastewater, nor in the supplemented RAS wastewater in this study. However, it is known that some of the TEs are already present in seawater or artificial sea salt (Supplementary Material, Table S1). With the exception of B (1580 times higher), all of the other TEs were present, but at a lower (20-270 times) concentration in the synthetic salt used to supplement the RAS wastewater (SEALIFE) compared with the TE mix. Therefore, some key TEs for the normal functioning of anammox could 
be present in too low or too high concentrations, while others could be present in sufficient concentrations in RAS wastewater and need to be further investigated.

TEs are essential for anammox metabolism and growth. For instance, $\mathrm{Mn}$ is an important element for the functioning of the superoxide dismutase enzyme [45]. In addition, $\mathrm{Mn}$ and Fe participate in the metabolism and proliferation of anammox bacteria through the synthesis of Haem-C [46]. Nitrogen removal efficiency has been increased with Fe $\left(0.08 \mathrm{mmol} \mathrm{L}^{-1}\right.$; ca $\left.4.47 \mathrm{mg} \mathrm{L}^{-1}\right)$ and $\mathrm{Mn}\left(0.05 \mathrm{mmol} \mathrm{L}^{-1}\right.$; ca $\left.2.75 \mathrm{mg} \mathrm{L}^{-1}\right)$ supplementation [46]. In another study, short-term exposure to $\mathrm{Mn}\left(2 \mathrm{mg} \mathrm{L}^{-1}\right), \mathrm{Zn}\left(2 \mathrm{mg} \mathrm{L}^{-1}\right)$ and $\mathrm{Cu}\left(0.5 \mathrm{mg} \mathrm{L}^{-1}\right)$ significantly improved the nitrogen removal rate of anammox reactors, while long-term exposure to those TE concentrations altered the microbial community structure of the anammox sludge [44]. Furthermore, too high concentrations of TEs can also negatively impact the anammox process. For instance, short-term $\mathrm{IC}_{50}$ values for $\mathrm{Cu}$ in freshwater anammox culture were found to be between 1.9 [47] and $12.9 \mathrm{mg} \mathrm{L}^{-1}$ [48]. For marine anammox species, studies on specific TE requirements are still scarce. $\mathrm{Li}$ and colleagues recently observed optimal ammonium removal efficiencies with $0.05 \mathrm{mmol} \mathrm{L}^{-1}$ $\left(2.75 \mathrm{mg} \mathrm{L}^{-1}\right) \mathrm{Mn}$ and $0.025 \mathrm{mmol} \mathrm{L}^{-1}\left(1.47 \mathrm{mg} \mathrm{L}^{-1}\right) \mathrm{Ni}$ [49]. It is, therefore, paramount that future studies investigate the specific TE requirement of the marine anammox species Ca. Scalindua.

If we analyze other possible causes of the reduction in bacterial removal activity such as $\mathrm{NO}_{2}{ }^{-}$, we can ascertain that the $\mathrm{NO}_{2}{ }^{-}$concentrations in the effluent were between 0.0 and $35.4 \mathrm{mg}-\mathrm{N} \mathrm{L} \mathrm{L}^{-1}$ depending on the phase. Awata and colleagues reported that the tolerance of $\mathrm{NO}_{2}{ }^{-}$for $\mathrm{Ca}$. Scalindua was $7.5 \mathrm{mmol} \mathrm{L}^{-1}\left(=105 \mathrm{mg}-\mathrm{N} \mathrm{L}^{-1}\right)$ [25]. Therefore, $35.4 \mathrm{mg}-\mathrm{N} \mathrm{L}^{-1}$ of $\mathrm{NO}_{2}{ }^{-}$accumulation can be excluded as a negative metabolic effect for the anammox activity.

Regarding the anammox stoichiometry, the ratios of $\mathrm{NO}_{2}{ }^{-} / \mathrm{NH}_{4}{ }^{+}$and $\mathrm{NO}_{3}{ }^{-} / \mathrm{NH}_{4}{ }^{+}$ were 1.56 and -0.16 , respectively, at the end of Phase 1, indicating similar anammox stoichiometry as that found in other marine anammox cultures [31]. During Phase 2, the stoichiometric ratio of $\mathrm{NO}_{2}{ }^{-} / \mathrm{NH}_{4}{ }^{+}$was slightly over 2 . However, these values were not stable and not reliable, as in fact, the ratio of $\mathrm{NO}_{2}{ }^{-} / \mathrm{NH}_{4}{ }^{+}$depends on the $\mathrm{NH}_{4}{ }^{+}$ concentration, and the $\mathrm{NH}_{4}{ }^{+}$removal efficiency was less than $10 \%$ during this phase.

The consumption of $\mathrm{NO}_{2}{ }^{-}$and $\mathrm{NO}_{3}{ }^{-}$is important for assessing eventual heterotrophic denitrification. As we observed no difference in the consumption of both, we concluded that there was no occurrence of heterotrophic denitrification. This was further confirmed by the low and stable population of heterotrophic denitrifying bacteria in the microbial community.

\subsection{Microbial Community}

FISH and the microbiological analysis testified a stable population of $\mathrm{Ca}$. Scalindua during the experiment, noting that the decrease in the TN removal rate was probably not caused by a decrease in anammox bacterial population abundance but rather by a decrease in the anammox activity of the $\mathrm{Ca}$. Scalindua present.

The relative abundances of bacterial phyla in the three biomass samples showed an increase in Actinomarinales (Actinobacteria), OC31 (Bacteroidetes), Balneolaceae (Bacteroidetes), Anaerolineaceae (Chloroflexi) and Rhodobacteraceae (Alphaproteobacteria), whereas OM190 (Planctomycetes) and Ulvibacter (Bacteroidetes) were decreased over the experimental period (Figure 3). Changes in the bacterial communities could be due to the presence of high protein concentrations or the presence of other organic and inorganic residues from feces and uneaten feed in the RAS wastewater (Phases 2, 3 and 4). Previous studies on organicmatter-rich synthetic wastewater and animal manure have proven to have adverse effects on anammox bacteria in favor of anaerobic denitrifying bacteria [50-52]. In addition to reduced anammox activity, organic-rich livestock manure can impact the microbial community structure and the spatial distribution in the outer layer of the anammox granules, with an increased density of co-existing heterotrophic bacteria [53]. Such bacteria are successful competitors and may thrive with the excess of organic matter. For example, Actinomari- 
nales with opportunistic copiotrophic lifestyles may experience the presence of particulate organic matter as an advantageous micro-heterogeneity [54]. Chloroflexi can fermentatively utilize sugars and protein compounds [55], and Bacteroidetes are polysaccharide-degrading bacteria, highly successful competitors in gut ecosystems [56]. OM190 and Ulvibacter are both strictly aerobic $[57,58]$. Their presence at a relatively high proportion in the inoculum ( $14 \%$ and $21 \%$, respectively) is probably due to the exposure of the biomass to aerobic conditions while setting up the reactor, while their decline in proportion with time could be attributed to the re-establishment of anaerobic conditions.

\section{Conclusions}

The present study demonstrates that $C a$. Scalindua can potentially be used to treat wastewater from RAS. However, the activity of $\mathrm{Ca}$. Scalindua rather than its relative abundance was affected by unknown compounds in the RAS wastewater and/or an imbalance in certain TEs. In this study, a much higher concentration of $\mathrm{NO}_{3}{ }^{-}$was present in the RAS wastewater due an efficient but sole nitrification in the RAS system. Further studies need to determine the effect of nitrate on the kinetic activity of nitrogen removal by anammox organisms. Anammox had the ability to resume its activity with high removal efficiencies once the synthetic medium was reintroduced. This leads us to understand that there is a reduction potential even with the use of RAS wastewater, but it is necessary to understand what the correct acclimatization for the organisms is and which elements cause a loss in removal efficiency in order to understand how these factors can be mitigated to improve the removal activity of these bacteria. Future studies also need to address specifically which concentrations of TEs are necessary for maintaining the anammox activity and/or growth of $\mathrm{Ca}$. Scalindua to apply for RAS wastewater treatment.

Supplementary Materials: The following are available online at https://www.mdpi.com/article/10 .3390/pr9071183/s1. Table S1: Comparison of TE concentrations.

Author Contributions: Conceptualization, J.A.C.R., F.M. and T.K.; methodology, J.A.C.R., F.M., S.H. and T.K.; software, T.K.; validation, T.K.; formal analysis, J.A.C.R., F.M. and T.K.; investigation, J.A.C.R., F.M., S.H. and T.K.; resources, J.A.C.R., K.S. and T.K.; data curation, J.A.C.R., F.M. and T.K.; writing-original draft preparation, J.A.C.R., F.M. and T.K.; writing-review and editing, J.A.C.R., F.M., K.S. and T.K.; visualization, J.A.C.R., F.M. and T.K.; supervision, K.S. and T.K.; project administration, J.A.C.R.; funding acquisition, J.A.C.R., K.S. and T.K. All authors have read and agreed to the published version of the manuscript.

Funding: This research was conducted within the frame of the MIRAI project and was partly supported by the Helge Axelsson Johnsons foundation, Stockholm, Sweden (F19-0425 and F200272); the Wilhelm and Martina Lundgrens foundation, Gothenburg, Sweden (2020-3431); STINT, Stockholm, Sweden (initiation grant for international collaboration, IB2019-8110); JSPS KAKENHI Grant Number JP20KK0244, Japan; and the JSPS Bilateral Program, Grant number JPJSBP120219926.

Institutional Review Board Statement: Not applicable.

Informed Consent Statement: Not applicable.

Data Availability Statement: The sequence data in the present study were deposited in the DNA Data Bank of Japan (DDBJ) database under the DDBJ/EMBL/GenBank accession number DRA010899.

Acknowledgments: The RAS wastewater was obtained from Smögenlax Aquaculture AB, Kungshamn, Sweden. We are grateful to Miyuki Kuribara for proofreading and copy-editing this manuscript.

Conflicts of Interest: The authors declare no conflict of interest.

\section{References}

1. United Nations, Department of Economic and Social Affairs, Population Division. World Population Prospects, Online edition; Rev. 1; United Nations, Department of Economic and Social Affairs: New York, NY, USA, 2019.

2. Béné, C.; Barange, M.; Subasinghe, R.; Pinstrup-Andersen, P.; Merino, G.; Hemre, G.-I.; Williams, M. Feeding 9 billion by 2050-Putting fish back on the menu. Food Secur. 2015, 7, 261-274. [CrossRef] 
3. FAO. The State of World Fisheries and Aquaculture Sustainability in Action; Food and Agriculture Organization of the United Nations: Rome, Italy, 2020.

4. Pahri, S.D.R.; Mohamed, A.F.; Samat, A. LCA for open systems: A review of the influence of natural and anthropogenic factors on aquaculture systems. Int. J. Life Cycle Assess. 2015, 20, 1324-1337. [CrossRef]

5. Martins, C.; Eding, E.H.; Verdegem, M.C.; Heinsbroek, L.T.; Schneider, O.; Blancheton, J.-P.; d'Orbcastel, E.R.; Verreth, J. New developments in recirculating aquaculture systems in Europe: A perspective on environmental sustainability. Aquacult. Eng. 2010, 43, 83-93. [CrossRef]

6. Kolarevic, J.; Baeverfjord, G.; Takle, H.; Ytteborg, E.; Reiten, B.K.M.; Nergård, S.; Terjesen, B.F. Performance and welfare of Atlantic salmon smolt reared in recirculating or flow through aquaculture systems. Aquaculture 2014, 432, 15-25. [CrossRef]

7. Mota, V.C.; Nilsen, T.O.; Gerwins, J.; Gallo, M.; Ytteborg, E.; Baeverfjord, G.; Kolarevic, J.; Summerfelt, S.T.; Terjesen, B.F. The effects of carbon dioxide on growth performance, welfare, and health of Atlantic salmon post-smolt (Salmo salar) in recirculating aquaculture systems. Aquaculture 2019, 498, 578-586. [CrossRef]

8. Roques, J.A.C. Aspects of Fish Welfare in Aquaculture Practices. Ph.D. Thesis, Radboud University Nijmegen, Nijmegen, The Netherlands, 2013.

9. Van Rijn, J.; Ebeling, J. Recirculating Aquaculture; Ventures: Ithaca, NY, USA, 2010; pp. 387-424.

10. Chen, S. Recirculating Systems Effluents and Treatments; Aquaculture and the Environment in the United States, World Aquaculture Society: Baton Rouge, LA, USA, 2002; pp. 119-140.

11. Camargo, J.A.; Alonso, A.; Salamanca, A. Nitrate toxicity to aquatic animals: A review with new data for freshwater invertebrates. Chemosphere 2005, 58, 1255-1267. [CrossRef]

12. Sindilariu, P.-D.; Brinker, A.; Reiter, R. Waste and particle management in a commercial, partially recirculating trout farm. Aquacult. Eng. 2009, 41, 127-135. [CrossRef]

13. Stavrakidis-Zachou, O.; Ernst, A.; Steinbach, C.; Wagner, K.; Waller, U. Development of denitrification in semi-automated moving bed biofilm reactors operated in a marine recirculating aquaculture system. Aquac. Int. 2019, 27, 1485-1501. [CrossRef]

14. Hu, Z.; Lee, J.W.; Chandran, K.; Kim, S.; Khanal, S.K. Nitrous oxide (N2O) emission from aquaculture: A review. Environ. Sci. Technol. 2012, 46, 6470-6480. [CrossRef] [PubMed]

15. Kuenen, J.G. Anammox bacteria: From discovery to application. Nat. Rev. Microbiol. 2008, 6, 320-326. [CrossRef]

16. Schmid, M.; Walsh, K.; Webb, R.; Rijpstra, W.I.; van de Pas-Schoonen, K.; Verbruggen, M.J.; Hill, T.; Moffett, B.; Fuerst, J.; Schouten, S. Candidatus "Scalindua brodae", sp. nov., Candidatus "Scalindua wagneri", sp. nov., two new species of anaerobic ammonium oxidizing bacteria. Syst. Appl. Microbiol. 2003, 26, 529-538. [CrossRef] [PubMed]

17. Mojiri, A.; Ohashi, A.; Ozaki, N.; Aoi, Y.; Kindaichi, T. Integrated anammox-biochar in synthetic wastewater treatment: Performance and optimization by artificial neural network. J. Clean. Prod. 2020, 243, 118638. [CrossRef]

18. Preena, P.G.; Rejish Kumar, V.J.; Singh, I.S.B. Nitrification and denitrification in recirculating aquaculture systems: The processes and players. Rev. Aqua. 2021. [CrossRef]

19. Jetten, M.S.; Niftrik, L.v.; Strous, M.; Kartal, B.; Keltjens, J.T.; Op den Camp, H.J. Biochemistry and molecular biology of anammox bacteria. Crit. Rev. Biochem. Mol. Biol. 2009, 44, 65-84. [CrossRef] [PubMed]

20. Lahav, O.; Massada, I.B.; Yackoubov, D.; Zelikson, R.; Mozes, N.; Tal, Y.; Tarre, S. Quantification of anammox activity in a denitrification reactor for a recirculating aquaculture system. Aquaculture 2009, 288, 76-82. [CrossRef]

21. Tal, Y.; Watts, J.E.; Schreier, H.J. Anaerobic ammonium-oxidizing (anammox) bacteria and associated activity in fixed-film biofilters of a marine recirculating aquaculture system. Appl. Environ. Microbiol. 2006, 72, 2896-2904. [CrossRef]

22. van Kessel, M.A.; Harhangi, H.R.; van de Pas-Schoonen, K.; van de Vossenberg, J.; Flik, G.; Jetten, M.S.; Klaren, P.H.; den Camp, H.J.O. Biodiversity of $\mathrm{N}$-cycle bacteria in nitrogen removing moving bed biofilters for freshwater recirculating aquaculture systems. Aquaculture 2010, 306, 177-184. [CrossRef]

23. Schreier, H.J.; Mirzoyan, N.; Saito, K. Microbial diversity of biological filters in recirculating aquaculture systems. Curr. Opin. Biotechnol. 2010, 21, 318-325. [CrossRef] [PubMed]

24. Tal, Y.; Schreier, H.J.; Sowers, K.R.; Stubblefield, J.D.; Place, A.R.; Zohar, Y. Environmentally sustainable land-based marine aquaculture. Aquaculture 2009, 286, 28-35. [CrossRef]

25. Awata, T.; Oshiki, M.; Kindaichi, T.; Ozaki, N.; Ohashi, A.; Okabe, S. Physiological characterization of an anaerobic ammoniumoxidizing bacterium belonging to the "Candidatus Scalindua" group. Appl. Environ. Microbiol. 2013, 79, 4145-4148. [CrossRef] [PubMed]

26. Kindaichi, T.; Awata, T.; Tanabe, K.; Ozaki, N.; Ohashi, A. Enrichment of marine anammox bacteria in Hiroshima Bay sediments. Water Sci. Technol. 2011, 63, 964-969. [CrossRef]

27. Oshiki, M.; Awata, T.; Kindaichi, T.; Satoh, H.; Okabe, S. Cultivation of planktonic anaerobic ammonium oxidation (anammox) bacteria using membrane bioreactor. Microbes Environ. 2013, 28, 436-443. [CrossRef] [PubMed]

28. Awata, T.; Kindaichi, T.; Ozaki, N.; Ohashi, A. Biomass yield efficiency of the marine anammox bacterium, "Candidatus Scalindua sp.," is affected by salinity. Microbes Environ. 2015, 30, 86-91. [CrossRef] [PubMed]

29. Brijs, J.; Hjelmstedt, P.; Berg, C.; Johansen, I.; Sundh, H.; Roques, J.; Ekström, A.; Sandblom, E.; Sundell, K.; Olsson, C. Prevalence and severity of cardiac abnormalities and arteriosclerosis in farmed rainbow trout (Oncorhynchus mykiss). Aquaculture 2020, 526, 735417. [CrossRef] 
30. Van de Graaf, A.A.; de Bruijn, P.; Robertson, L.A.; Jetten, M.S.; Kuenen, J.G. Autotrophic growth of anaerobic ammonium-oxidizing micro-organisms in a fluidized bed reactor. Microbiology 1996, 142, 2187-2196. [CrossRef]

31. Kindaichi, T.; Awata, T.; Suzuki, Y.; Tanabe, K.; Hatamoto, M.; Ozaki, N.; Ohashi, A. Enrichment Using an Up-flow Column Reactor and Community Structure of Marine Anammox Bacteria from Coastal Sediment. Microbes Environ. 2011, 26 , 67-73. [CrossRef] [PubMed]

32. Mojiri, A.; Nishimoto, K.; Awata, T.; Aoi, Y.; Ozaki, N.; Ohashi, A.; Kindaichi, T. Effects of salts on the activity and growth of "Candidatus Scalindua sp.", a marine Anammox bacterium. Microbes Environ. 2018, 33, 336-339. [CrossRef]

33. APHA; AWWA; WEF. Standard Methods for the Examination of Water and Wastewater; American Public Health Association: Washington, DC, USA, 2012.

34. Shoiful, A.; Kambara, H.; Cao, L.T.T.; Matsushita, S.; Kindaichi, T.; Aoi, Y.; Ozaki, N.; Ohashi, A. Mn (II) oxidation and manganese-oxide reduction on the decolorization of an azo dye. Int. Biodeter. Biodeg. 2020, 146, 104820. [CrossRef]

35. Awata, T.; Goto, Y.; Kuratsuka, H.; Aoi, Y.; Ozaki, N.; Ohashi, A.; Kindaichi, T. Reactor performance and microbial community structure of single-stage partial nitritation anammox membrane bioreactors inoculated with Brocadia and Scalindua enrichment cultures. Biochem. Eng. J. 2021, 170, 107991. [CrossRef]

36. Bolyen, E.; Rideout, J.R.; Dillon, M.R.; Bokulich, N.A.; Abnet, C.; Al-Ghalith, G.A.; Alexander, H.; Alm, E.J.; Arumugam, M.; Asnicar, F. QIIME 2: Reproducible, Interactive, Scalable, and Extensible Microbiome Data Science. PeerJ 2018, 2167-9843. [CrossRef]

37. Quast, C.; Pruesse, E.; Yilmaz, P.; Gerken, J.; Schweer, T.; Yarza, P.; Peplies, J.; Glöckner, F.O. The SILVA ribosomal RNA gene database project: Improved data processing and web-based tools. Nucleic Acids Res. 2012, 41, D590-D596. [CrossRef]

38. Daims, H.; Brühl, A.; Amann, R.; Schleifer, K.-H.; Wagner, M. The domain-specific probe EUB338 is insufficient for the detection of all Bacteria: Development and evaluation of a more comprehensive probe set. Syst. Appl. Microbiol. 1999, 22, 434-444. [CrossRef]

39. Schmid, M.C.; Maas, B.; Dapena, A.; van de Pas-Schoonen, K.; van de Vossenberg, J.; Kartal, B.; van Niftrik, L.; Schmidt, I.; Cirpus, I.; Kuenen, J.G. Biomarkers for in situ detection of anaerobic ammonium-oxidizing (anammox) bacteria. Appl. Environ. Microbiol. 2005, 71, 1677-1684. [CrossRef]

40. Tsushima, I.; Ogasawara, Y.; Kindaichi, T.; Satoh, H.; Okabe, S. Development of high-rate anaerobic ammonium-oxidizing (anammox) biofilm reactors. Water Res. 2007, 41, 1623-1634. [CrossRef]

41. Yamamoto, T.; Takaki, K.; Koyama, T.; Furukawa, K. Long-term stability of partial nitritation of swine wastewater digester liquor and its subsequent treatment by Anammox. Bioresour. Technol. 2008, 99, 6419-6425. [CrossRef]

42. Okabe, S.; Oshiki, M.; Takahashi, Y.; Satoh, H. Development of long-term stable partial nitrification and subsequent anammox process. Bioresour. Technol. 2011, 102, 6801-6807. [CrossRef]

43. Kimura, Y.; Isaka, K. Evaluation of inhibitory effects of heavy metals on anaerobic ammonium oxidation (anammox) by continuous feeding tests. Appl. Microbiol. Biot. 2014, 98, 6965-6972. [CrossRef]

44. Li, H.; Yao, H.; Zhang, D.; Zuo, L.; Ren, J.; Ma, J.; Pei, J.; Xu, Y.; Yang, C. Short-and long-term effects of manganese, zinc and copper ions on nitrogen removal in nitritation-anammox process. Chemosphere 2018, 193, 479-488. [CrossRef] [PubMed]

45. Aklujkar, M.; Coppi, M.V.; Leang, C.; Kim, B.C.; Chavan, M.; Perpetua, L.; Giloteaux, L.; Liu, A.; Holmes, D. Proteins involved in electron transfer to Fe (III) and Mn (IV) oxides by Geobacter sulfurreducens and Geobacter uraniireducens. Microbiology 2013, 159, 515-535. [CrossRef] [PubMed]

46. Huang, X.; Gao, D.; Peng, S.; Tao, Y. Effects of ferrous and manganese ions on anammox process in sequencing batch biofilm reactors. J. Environ. Sci. 2014, 26, 1034-1039. [CrossRef]

47. Lotti, T.; Cordola, M.; Kleerebezem, R.; Caffaz, S.; Lubello, C.; Van Loosdrecht, M. Inhibition effect of swine wastewater heavy metals and antibiotics on anammox activity. Water Sci. Technol. 2012, 66, 1519-1526. [CrossRef]

48. Yang, G.-F.; Ni, W.-M.; Wu, K.; Wang, H.; Yang, B.-E.; Jia, X.-Y.; Jin, R.-C. The effect of Cu (II) stress on the activity, performance and recovery on the anaerobic ammonium-oxidizing (Anammox) process. Chem. Eng. J. 2013, 226, 39-45. [CrossRef]

49. Li, J.; Feng, L.; Qiang, Z.; Dong, H.; Wang, D. Enhanced performance and kinetics of marine anammox bacteria (MAB) treating nitrogen-rich saline wastewater with Mn (II) and Ni (II) addition. Bioresour. Technol. 2018, 249, 1085-1091. [CrossRef] [PubMed]

50. Molinuevo, B.; García, M.C.; Karakashev, D.; Angelidaki, I. Anammox for ammonia removal from pig manure effluents: Effect of organic matter content on process performance. Bioresour. Technol. 2009, 100, 2171-2175. [CrossRef]

51. Jin, R.-C.; Yang, G.-F.; Yu, J.-J.; Zheng, P. The inhibition of the Anammox process: A review. Chem. Eng. J. 2012, 197, 67-79. [CrossRef]

52. Chamchoi, N.; Nitisoravut, S.; Schmidt, J.E. Inactivation of ANAMMOX communities under concurrent operation of anaerobic ammonium oxidation (ANAMMOX) and denitrification. Bioresour. Technol. 2008, 99, 3331-3336. [CrossRef] [PubMed]

53. Kindaichi, T.; Awata, T.; Mugimoto, Y.; Rathnayake, R.M.; Kasahara, S.; Satoh, H. Effects of organic matter in livestock manure digester liquid on microbial community structure and in situ activity of anammox granules. Chemosphere 2016, 159, 300-307. [CrossRef]

54. Mizuno, C.M.; Rodriguez-Valera, F.; Ghai, R. Genomes of planktonic acidimicrobiales: Widening horizons for marine actinobacteria by metagenomics. MBio 2015, 6, e02083-14. [CrossRef]

55. Yamada, K.; Oomaru, K.; Nakamura, S.; Sato, T.; Nakatani, Y. Reducing the switching current with a Gilbert damping constant in nanomagnets with perpendicular anisotropy. Appl. Phys. Lett. 2015, 106, 042402. [CrossRef] 
56. Robinson, R.K. Encyclopedia of Food Microbiology; Academic Press: San Diego, CA, USA, 2014.

57. Nedashkovskaya, O.I.; Kim, S.B.; Han, S.K.; Rhee, M.S.; Lysenko, A.M.; Falsen, E.; Frolova, G.M.; Mikhailov, V.V.; Bae, K.S. Ulvibacter litoralis gen. nov., sp. nov., a novel member of the family Flavobacteriaceae isolated from the green alga Ulva fenestrata. Int. J. Syst. Evol. Microbiol. 2004, 54, 119-123. [CrossRef]

58. Lage, O.M.; Bondoso, J. Planctomycetes and macroalgae, a striking association. Front. Microbiol. 2014, 5, 267. [CrossRef] 